\title{
Exchange Rate, Foreign Direct Investment and Economic Growth Nexus in Nigeria
}

\author{
Onabote Ademola Andrew ${ }^{1}$, Adama Ibrahim Joseph ${ }^{1}$, Obasaju Barnabas ${ }^{1}$, Bright \\ Ohwofasa $^{2}$, Eluyela Damilola ${ }^{3}$, Popoola Olabisi ${ }^{1}$
}

\author{
${ }^{1}$ Department of Economics, Landmark University,Omu-Aran,Kwara State,Nigeria. \\ ${ }^{2}$ Department of Social Sciences (Economics Unit)Delta State Polytechnic, Otefe-Oghara, Delta State, Nigeria. \\ ${ }^{3}$ Department of Accounting and Finance, Landmark University,Omu-Aran, Kwara State,Nigeria.
}

Received: 06 Dec 2021; Received in revised form: 09 Feb 2022; Accepted: 16 Feb 2022; Available online: 24 Feb 2022 (C)2022 The Author(s). Published by Infogain Publication. This is an open access article under the CC BY license (https://creativecommons.org/licenses/by/4.0/).

\begin{abstract}
The relationship among exchange rate, foreign direct investment and economic growth is explored in this study by adopting the Autoregressive Distributive Lag (ARDL) technique to examine the long-run cointegrating relationship for the period 1981-2018. A long-run relationship was confirmed among exchange rate, foreign direct investment and economic growth. From the findings, foreign direct investment contributes positively to economic growth, while the speed of adjustment is $78.46 \%$ and significant.The study recommends, among others, that the Nigerian government must create an enabling atmosphere for private businesses to prosper. The study suggested that the government pursue policies that will boost investors' confidence and enable foreign companies to invest in the country's economy. Government and private-sector agencies are encouraged to invest more in the country's education and health care infrastructure.
\end{abstract}

Keywords-Exchange rate, Foreign direct investment, Economic growth, ARDL, Nigeria.

\section{INTRODUCTION}

Economic growth is a major focus of most developing countries in the world, and Nigeria is not left out. However, despite the government's several attempts to promote growth, weak investment policy, weak exchange rate policy and over-reliant on revenue generated from the sales of crude oil export while completely ignoring the other sectors of the economy where huge income could be generated, has hindered this plan.

From literature, exchange rate and foreign direct investment (FDI) are vital variables that stimulate economic growth. The main contribution of FDI to economic growth is an increase in productivity due to improved technology. In 2001, Nigeria recorded domestic savings of $34.33 \%$ and $14.27 \%$ in 2015 , but this figure increased slightly to $17.81 \%$ trillion in 2018. (World Bank, 2020). Nevertheless, the domestic savings ratio is still relatively low, so the need to close the fiscal deficit gapusing FDI.FDI has been on the increase in Nigeria since 1981 when it was $\$ 542$ million to about $\$ 8.84$ million in 2011. Following the rapid insecurity recorded across Nigeria since 2011 and the global financial crises since then, the foreign inflow has continued to experience a downward trend going as low as only $\$ 1.99$ billion in 2018.The case is no different for the world's leading economic (The United States), foreign direct investment value has also been on a downward trajectory since 2015 . In 2018 the United States recorded an FDI inflow of 1.19 trillion (World Bank, 2020).

Studies on FDI are focused on the flow within developed countries and pay less attention to the flow from developed to developing countries (Alabi, 2019). FDI is a significant capital inflow source and has reasonably been on the increase (Antwi et al., 2013).Some of the advantages of FDI include developing new technology leading to new production techniques that lead to improved productivity and revenue generation from taxes for the federal 
government. Therefore, it is not surprising that FDI is perceived to be an instrument to promote growth and development. Therefore, it is not surprising that FDI is seen as an instrument to promote growth and development. (Pegkas, 2015; Umeora, 2013).

A crucial macroeconomic instrument used to resolve foreign transactions and balance of payment deficits is the exchange rate. Consequently, central banks in individual countries are very critical of the value of exchange and strive to ensure its stability. Nigeria and many developing counties have sufferedfrom exchange rate devaluations. The Nigerian economy went into recession in 2016, andthis unfavourable economic phenomenon adversely affected almost all spheres of the country's economy. Indicator from the country's capital market was abysmal. The signal from the Nigerian foreign exchange market was appalling. Aside from the fact that there was undue high volatility in the country's exchange rate, Nigeria's actual exchange rate at a given point in time within this period was hard to determine. From 2016 to 2020, when this study was conducted, the Nigerian foreign exchange market has been severed into two. The official market and the unofficial market popularly called the parallel market. Although the official market is recognised and reported by the Central Bank of Nigeria, the parallel market appeared to be the most patronised by individuals and corporate entities for foreign exchange transactions. Hence, activities in the parallel market seem to affect economic activities more. There is a vast difference in the costs of transactions in both markets.

To the best of our knowledge, few studies such as (Asteriou et al., 2016; Basirat et al., 2014; Kenny, 2019; Ojo \& Alege, 2014; Osinubi et al., 2009) exist.Studies such as (Uzoma-Nwosu \& Orekoya, 2019; Ojo \& Alege, 2014) concentrated on exchange rate fluctuations on economic growth. Others such as (Khalighi \& Fadaei, 2017 and Kenny, 2019) studied the effects of the exchange rate and foreign direct investment on specific sectors, such as the impact of export on the economy.In terms of foreign direct investment, many of these studies are focused on the flow from developed countries to developing countries. Although a growing literature on economic growth, exchange rate and foreign direct investment has been uncovered, relatively little is known about Nigeria. Given the importance of exchange and FDI to the Nigerian economy, this study examines the relationship between exchange rate foreign direct investment and Nigeria's economic growth. Following this introduction section, other sections of this study are: Section 2 which deals with insight from empirical literature, section 3 presents the methodology, section 4 presents the results and discussion, and finally, the conclusion comes in section 5 .

\section{INSIGHTS FROM EMPIRICAL LITERATURE}

There have consistent arguments regarding the impact of FDI on economic growth in an economy, which has resulted in mixed evidence. Some authors (Ehimare, 2011; Mokuolu, 2018; Sokang, 2018) opined that FDI spurs economic growth, leading to economic prosperity. In contrast, the other school of thought (like Akinlo, 2004; Nwanji et al., 2020) believes that FDI does not significantly impact economic growth.

The Autoregressive Distributed Lag Model (ARDL) was employed by Sunde (2017) to examine quantitatively, the relationship between foreign direct investments, exports and economic growth. The research was focused on the economy of South Africa. The short-term dynamics were analysed in an error correction model, and the VECM Granger causality approach was utilised to analyse the causal effects. Cointegration between economic growth, foreign direct investment and exports were verified in the study. The analysis found that foreign direct investment and exports were enhancing South Africa's economic growth. A unidirectional causal relationship is found between foreign direct investment and economic growth, foreign direct investment and exports while a two-way causality between economic growth and exports. Similarly, Sokang (2018) assessed the impact of FDI on Cambodia's economic growth. Using data from 2006 to 2016, the findings show that FDI has a significant positive relationship with Cambodia's economic growth.

The study of Mokuolu (2018) added exchange and interest rate as a moderating variable in examining the impact of FDI on economic growth in Nigeria. The study of Ehimare (2011) used inflation as a moderating variable in addition to the exchange rate in investigating the relationship between FDI and economic growth in Nigeria. The study shows FDI and trade openness to be a significant contributor to the economy leading to the entry of several big companies,in particular those in the telecommunications sector. Meanwhile, the study found that inflation does not have an impact on FDI. However, the exchange rate affects FDI.

A recent study by Ogu (2020) examined the effect of exchange rate fluctuation, interest rate, inflation, gross fixed capital formation and gross domestic product on foreign direct investment in Nigeria. The results indicated that exchange rate fluctuation has a positive relationship with foreign direct investment. The result also shows that 
interest rate and inflation contributed positively to the inflow of foreign direct investment in Nigeria. Simultaneously, variables such as gross fixed capital formation and gross domestic product negatively affect the inflow of foreign direct investment in Nigeria.

The impact of foreign direct investment on economic growth can be statistically insignificant, as seen in Akinlo (2004) study. The article investigated the impact of foreign direct investment (FDI) on Nigeria's economic growth for the period 1970-2001. Using Error Correction Model (ECM), the results show that both private capital and lagged foreign capital have small, and not statistically significant, economic growth. The results seem to support the argument that extractive FDI might not be growthenhancing as much as manufacturing FDI. Finally, the results show that labour force and human capital have a significant positive effect on growth.

\section{METHODOLOGY}

The dependent variable is the real gross domestic product, a proxy for economic growth, while the explanatory variables are gross capital formation, labour, exchange rate, inflation and interest rate.
The model is specified in its implicit form as:

$r g d p=f(g c f, l a b, f d i, r e x r$, inf, int $)$

$\operatorname{rgd} p_{t}=$

A. $g c f_{t}^{\beta_{1}} \cdot \operatorname{lab}_{t}^{\beta_{2}} f d i_{t}^{\beta_{3}} \cdot \operatorname{rexr}_{t}^{\beta_{4}} \cdot \inf ^{\beta_{5}} \cdot \operatorname{int}_{t}^{\beta_{6}} \cdot \varepsilon_{t}$

(2)

Both sides of the model are logged to make it linear

$\operatorname{lrgdp_{t}}=\beta_{0}+\beta_{1} \operatorname{lgc} f_{\mathrm{t}}+\beta_{2} l l a b_{t}+\beta_{3} l f d i_{t}+$ $\beta_{4}$ lrexr $_{t}+\beta_{5} \operatorname{linf}_{t}+\beta_{6}$ lint $_{t}+\varepsilon_{t}$ (3)

Where $r g d p$ represents economic growth proxied by real gross domestic product, $g c f$ represents gross capital formation, $l a b$ represent labour, $f d i$ represent foreign direct investment, rexr represent exchange rate, inf represent inflation, and int represents interest rate.

The use of quality and reliable data is advised when conducting an econometric analysis. Annual data from 1981 to 2018, comprising 38 years are used for the analysis. The data are sourced from the World Banks, World Development Indicators, and the Central bank of Nigeria (CBN)statistical bulletin.

Table 1. Data source and measurement

\begin{tabular}{|c|l|l|c|}
\hline S/N & \multicolumn{1}{|c|}{ Variable } & \multicolumn{1}{|c}{ Measurement } & \multicolumn{1}{|c}{ Source } \\
\hline $\mathbf{1}$ & Real gross domestic product $(\boldsymbol{r g d} \boldsymbol{p})$ & U.S. dollar & World Bank, WDI (2020) \\
$\mathbf{2}$ & Gross capital formation $(\boldsymbol{g} \boldsymbol{c} \boldsymbol{f})$ & U.S. dollar & World Bank, WDI (2020) \\
$\mathbf{3}$ & Labour(lab) & Number of people & World Bank, WDI (2020) \\
$\mathbf{4}$ & Foreign direct investment $(\boldsymbol{f d i})$ & U.S. dollar & World Bank, WDI (2020) \\
$\mathbf{5}$ & Exchange rate $(\boldsymbol{r e x r})$ & 1 U.S. dollar / Naira & World Bank, WDI (2020) \\
$\mathbf{6}$ & Inflation $(\boldsymbol{i n f})$ & Percentage & World Bank, WDI (2020) \\
$\mathbf{7}$ & Interest rate $(\boldsymbol{i n t})$ & Percentage & World Bank, WDI (2020) \\
\hline
\end{tabular}

Source: Authors' Computation

The econometric method used is the Autoregressive Distributive Lag (ARDL). It is used to estimate the relationship among variables as it can estimate both the short-run relationship and an unbiased long run estimation among the variable (Popoola et al., 2018). The ARDL method's choice is based on some of its advantages over other cointegration methods, among which is the ability to estimate variables of different orders and its efficiency with relatively small sample size data(Harris \& Sollis, 2003).

The $\operatorname{ARDL}(p, q)$ model is presented in equation (4): 


$$
\begin{aligned}
\Delta \operatorname{lrgdp_{t}=} \beta_{0}+ & \alpha_{1} \operatorname{lrgdp}_{t-1}+\alpha_{2} \operatorname{lgcf}_{t-1}+\alpha_{3} \operatorname{llab}_{t-1}+\alpha_{4} l f d i_{t-1}+\alpha_{5} \operatorname{lrexr}_{t-1}+\alpha_{6} \operatorname{linf}_{t-1}+\alpha_{7} \operatorname{lint}_{t-1} \\
& +\sum_{i=1}^{q} \beta_{1} \Delta \operatorname{lrg} d p_{t-1}+\sum_{i=1}^{q} \beta_{2} \Delta l g c f_{t-1}+\sum_{i=1}^{q} \beta_{3} \Delta l l a b_{t-1}+\sum_{i=1}^{q} \beta_{4} \Delta l f d i_{t-1}+\sum_{i=1}^{q} \beta_{5} \Delta l r e x r_{t-1} \\
& +\sum_{i=1}^{q} \beta_{6} \Delta \operatorname{linf}_{t-1}+\sum_{i=1}^{q} \beta_{7} \Delta \operatorname{lint} t_{t-1}+\varepsilon_{t}
\end{aligned}
$$

The error correction model is presented in equation 5

$$
\begin{aligned}
& \Delta \operatorname{lrgdp} p_{t}=\beta_{0}+\sum_{i=1}^{p} \beta_{1} \Delta \operatorname{lrgdp_{t-1}}+\sum_{i=1}^{q} \beta_{2} \Delta \operatorname{lgc} f_{t-1} \sum_{i=1}^{q} \beta_{3} \Delta l \operatorname{la} b_{t-1}+\sum_{i=1}^{q} \beta_{4} \Delta l f d i_{t-1}+\sum_{i=1}^{q} \beta_{5} \Delta \operatorname{lrexr_{t-1}}+\sum_{i=1}^{q} \beta_{6} \Delta \operatorname{linf} f_{t-1} \\
& +\sum_{i=1}^{q} \beta_{7} \Delta \operatorname{lint}_{t-1}+\gamma E C T_{t-1}+\varepsilon_{t}
\end{aligned}
$$

Where $\beta_{0}$ is the constant; $\beta_{i}$ and $\alpha_{i}$ are the coefficient, $\Delta$ is the difference operator, $p$ and $q$ are the optimal lag order, $p$ is the dependent variable lag while $q$ is the independent variable lag, $t$ represents the time, ECT represent the error correction term, and $\gamma$ represents the speed of adjustment of the model.

\section{RESULTS AND DISCUSSION}

This section results from the econometric analysis such as unit root test, ARDL bounds test, stability and diagnostic test are reported.

\subsection{Unit Root Test}

This study uses the Augmented Dicky-Fuller unit root test to confirm the level stationarity of our variables. This is to avoid spurious result from the estimations process and validate that none of the variable used is integrated of order two [I(2)], which is an essential assumption of using the ARDL method (Osabohien et al., 2019). According to Osabohien et al. (2019), the bound test become ineffective when variables are integrated of order two I(2). The result of the Augmented Dickey-Fuller test is reported in Table 2 , it reveals that the dependent variable, labour and interest rate are not stationary at level, but they become stationary at the first difference.

All variables except foreign direct investment and inflation were stationary at order one I(1) while foreign direct investment and inflation were stationary at level $I(0)$. Therefore, we can go ahead with the desired estimation process as none of the variables is $I(2)$. Based on these results, we go-ahead to use the ARDL method of estimation.

Table 2. Augmented Dicky-Fuller (ADF) Unit root test

\begin{tabular}{c|c|c|c|c|c}
\hline Variable & $\begin{array}{c}\text { ADF } \\
\text { T-Stat. at } \\
\text { level }\end{array}$ & $\begin{array}{c}\text { Critical } \\
\text { Value }\end{array}$ & $\begin{array}{c}\text { ADF } \\
\text { T-Stat. at } \\
1^{\text {st }} \text { difference }\end{array}$ & $\begin{array}{c}\text { Critical } \\
\text { Value at } \\
5 \%\end{array}$ & Decision \\
\hline Real GDP & -2.037 & $-3.540^{* *}$ & -4.772 & $-3.540^{* *}$ & $-3.540^{* *}$ \\
\hline Labour & -0.945 & $-3.540^{* *}$ & -5.960 & - & $I(1)$ \\
\hline Capital & -3.827 & $-3.537^{* *}$ & - & $-3.540^{* *}$ & $I(1)$ \\
\hline Exchange rate & -1.975 & $-3.537^{* *}$ & -4.120 & - & $I(0)$ \\
\hline FDI & -3.486 & $-3.215^{* * *}$ & - & - & $I(0)$ \\
\hline Inflation & -3.962 & $-3.540^{* *}$ & - & $-3.544^{* *}$ & $I(1)$
\end{tabular}

$*, * *, \&^{* * *}$ denotes significance at $1 \%, 5 \%$ and $10 \%$ level respectively.

Source: Authors' Computation 


\subsection{ARDL Bound Test for cointegration}

The ARDL bound test is conducted to verify if a cointegrating relationship exists among the variables, and the result is presented in Table 3 . The bound test compares F-statistic value with the critical bound value by Pesaran et al. (2001) at both the upper and lower bound.The null hypothesis of no cointegration is rejected from the table since the F-Statistic of 4.686696 is greater than the upper bound value proposed by Pesaran et al. (2001) at the 1\%, $5 \%$ and $10 \%$ level of significance. Since cointegration is established, the error correction model can be specified.

Table 3. Bound test result at $5 \%$

\begin{tabular}{ccccc|}
\hline F-statistic & 4.686696 & Signif. & Lower Bound & Upper Bound \\
K & 6 & $10 \%$ & 1.99 & 2.94 \\
K & 6 & $5 \%$ & 2.27 & 3.28 \\
K & 6 & $1 \%$ & 2.88 & 3.99 \\
\hline
\end{tabular}

Source Authors' Computation using E-views 10

\subsection{ARDL estimates and Error Correction Model}

The result from the long run and short run ARDL estimate are presented in Tables 4 and 5. From the long run results, capital, labour and foreign direct investment positively affect economic growth. An increase in capital increases economic growth by $35.67 \%$. Also, an increase in labour brings about a positive increase in economic growth by approximately $110 \%$. Exchange rate and interest rate is inversely related to growth. A percentage increase in the exchange rate and interest rate brings about a respective $0.54 \%$ and $0.58 \%$ decrease in growth rate. These results are in line with a priori expectation. The contribution FDI is however, not significant in the long run. This is in line with the findings of Akinlo (2004). The effect of capital inflow may not be immediately felt due to the many current challenges faced by Nigerian but consistent increase will help to develop the production process leading to technological advancement which ultimately leads to economic growth in the long run. From the error correction model, the error correction term (ECT) is 0.784618 and significant. The negative and significant ECM implies the speed of adjustment of the model back to equilibrium is at approximately $78 \%$.

Table 4. ARDL long-run estimate

\begin{tabular}{|ccccc|}
\hline Series & Coefficient & Std. Error & T-Statistic & Probability \\
\hline $\operatorname{lgcf}$ & 0.356734 & 0.111693 & 3.193872 & 0.0085 \\
llab & 1.095445 & 0.212121 & 5.164253 & 0.0003 \\
lf $d i$ & 0.038514 & 0.062854 & 0.612763 & 0.5525 \\
lrexr & -0.250201 & 0.065046 & -3.846536 & 0.0027 \\
linf & 0.209407 & 0.064810 & 3.231074 & 0.0080 \\
lint & -0.359438 & 0.095287 & -3.772152 & 0.0031 \\
$C$ & 0.947322 & 0.422248 & 2.243521 & 0.0464 \\
\hline
\end{tabular}

Source: Authors' Computation using E-views 10

\section{EC $=$ LRGDP $-(0.3567 *$ LGCF + 1.0954*LLAB + 0.0385*LFDI -0.2502*LREXR \\ $+0.2094 *$ LINF $-0.3594 *$ LINT + 0.9473 )}

Table 5. ARDL Error Correction Model Regression

\begin{tabular}{|ccccc|}
\hline Series & Coefficient & Std. Error & T-Statistic & Probability \\
\hline$d(\operatorname{lrg} d p(-1))$ & 0.641354 & 0.114792 & 5.587106 & 0.0002 \\
$d(\lg c f)$ & 0.230462 & 0.043795 & 5.262292 & 0.0003 \\
$d(\lg c f(-1))$ & -0.119307 & 0.044013 & -2.710735 & 0.0203 \\
$d(\lg c f(-2))$ & -0.117168 & 0.038817 & -3.018450 & 0.0117 \\
\hline
\end{tabular}




\begin{tabular}{|ccccc|}
\hline$d($ lfdi $)$ & -0.083799 & 0.022903 & -3.658853 & 0.0038 \\
$d($ lfdi $(-1))$ & -0.097107 & 0.026525 & -3.661016 & 0.0037 \\
$d($ lfdi(-2)) & -0.041277 & 0.018432 & -2.239400 & 0.0468 \\
$d($ lrexr $)$ & 0.004048 & 0.021367 & 0.189428 & 0.8532 \\
$d($ linf $)$ & 0.001109 & 0.014513 & 0.076446 & 0.9404 \\
$d($ linf $(-1))$ & -0.069640 & 0.017733 & -3.927098 & 0.0024 \\
$d($ linf $(-2))$ & -0.118527 & 0.019506 & -6.076505 & 0.0001 \\
$d(\operatorname{lint})$ & -0.188661 & 0.024564 & -7.680517 & 0.0000 \\
$d(\operatorname{lint}(-1))$ & 0.126511 & 0.020578 & 6.147853 & 0.0001 \\
$d(\operatorname{lint}(-2))$ & 0.060141 & 0.016621 & 3.618443 & 0.0040 \\
ECT(-1)* & -0.784618 & 0.100171 & -7.832823 & 0.0000 \\
\hline
\end{tabular}

Source: Authors' Computation using E-views 10

\subsection{Diagnostic and Stability test}

Some diagnostic and stability tests are conducted and present in Table 6, Figures 1 and 2. From the results of the Breusch-Godfrey Serial correlation, there is no Auto Correlation problem since the P-value of 0.0721 is greater than $5 \%$. Also, revealed from the result is that there is no problem with heteroskedastic since the P-value of 0.1967 is greater than $5 \%$. The model is also normally distributed and possess no problem of misspecification.

Figure 1 and Figure 2 are the cumulative sum of recursive residuals and the cumulative sum of squares recursive residuals. The cumulative sum of recursive residuals and the cumulative sum of squares recursive residuals plot is within the $5 \%$ significant level ads indicated by the blue line from Figure 1 and 2.

Table 6. Summary of some diagnostic test

\begin{tabular}{lccl}
\hline \multicolumn{1}{c}{ Test } & Statistics & P-value & Decision \\
\hline Heteroscedasticity-Breusch-Pagan-Godfrey & 26.26041 & 0.1967 & No heteroskedasticity \\
Breusch-Godfrey-Serial Correlation & 5.259764 & 0.0721 & No Serial Correlation \\
Normality Test Jarque-Bera & 0.855768 & 0.65188 & Normally distributed \\
Ramsey Reset & 2.815474 & 0.1243 & No misspecification \\
\hline
\end{tabular}

Source: Authors' Computation using E-views 10

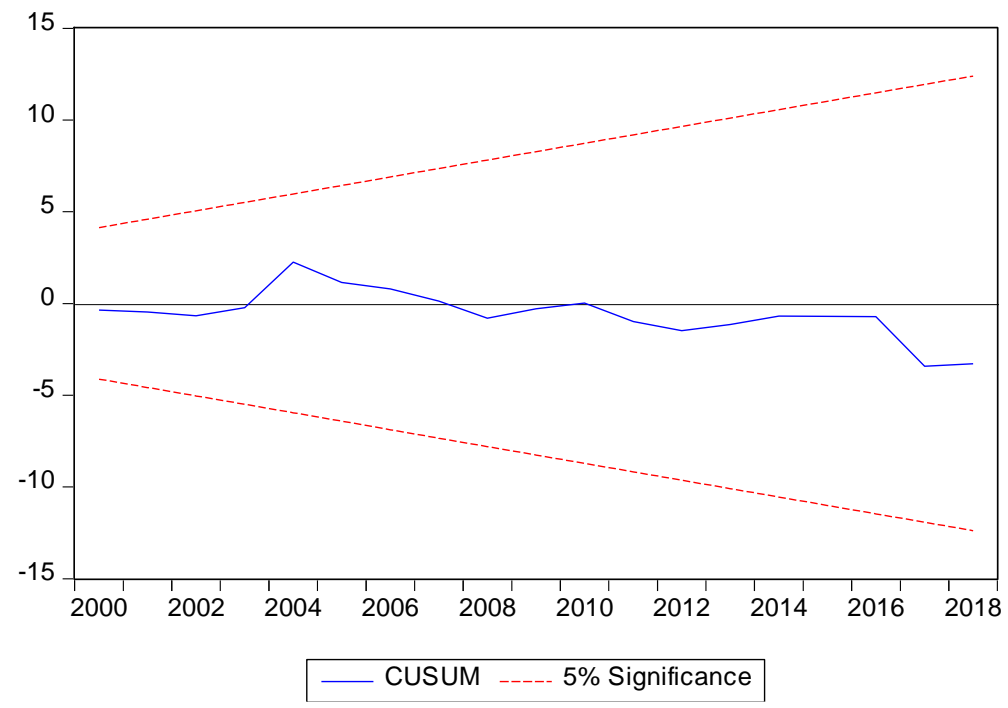

Fig.1. The cumulative sum of recursive residuals

Source: Authors' using E-views 10 


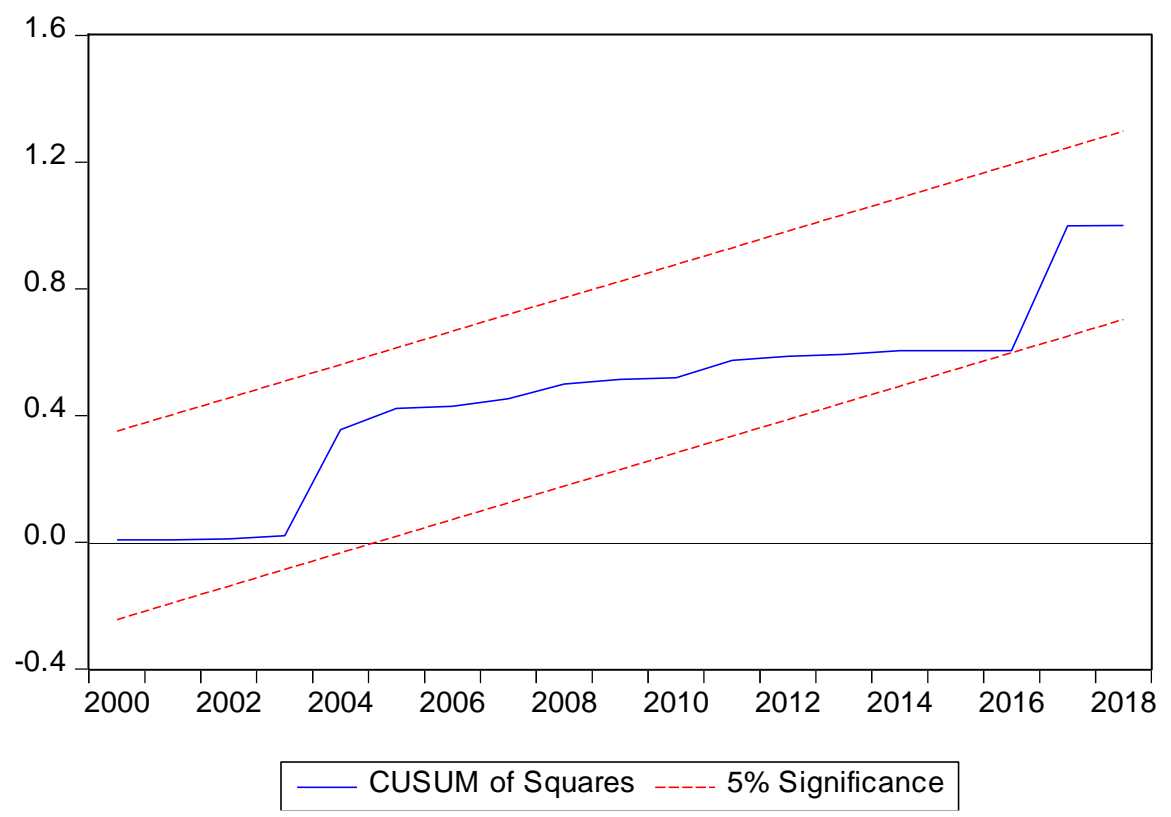

Fig.2. The cumulative sum of square recursive residuals

Source: Authors' using E-views 10

\subsection{Implication of Findings}

Based on the study's findings, depreciation in the Nigerian exchange rate is found to have a negative impact on the country's economic growth. In an economy with viable production capacity for manufacturing and exportation of goods and services, it is expected that a depleting foreign exchange would benefit more. However, the Nigerian economy's manufacturing sector has not been able to produce goods and services sufficiently enough to meet up with local demands, let alone exporting them. This has made the country a consuming economy. Larger proportions of Nigerian exports are primary produces which include crude oil and other raw agricultural produce. Because this category of products commands relatively low prices in the international market when compared with manufacture goods, it becomes difficult for the country to benefit from a lower exchange rate.

Furthermore, larger percentages of products used in Nigerian markets are imported. These items include automobiles, constructions equipment, computers, manufacturing and other service equipment are not produced locally. Hence, a fallen exchange rate makes their prices to skyrocket locally. There is no domestic producer to compete favourably with the imported product at a high price. The few manufacturing firms available in the country are sourcing major part of their inputs and workforce from overseas. A fallen exchange rate makes the cost of the input considerably high, hence their product prices as well. These two ways-imported manufactured product prices and imported manufacturing input price cause a fallen exchange rate to shrink the Nigerian economy's productive performance. This assertion corroborates the findings of Ehinomen and Oladipo (2012) and Mlambo (2020).

Moreover, an increase in FDI is empirically discovered to be an impetus for economic growth. With an increase in FDI inflow coupled with an expansion in the country's infrastructure base, the economy's production capacity will be enhanced, thereby causing a reduction in the unemployment rate. By implication, this will lead to increased output and hence promote economic growth. The submission is in line with the findings of Dinh et al. (2019) and Sasi and Mehmet (2015). Another exciting outcome is the positive contribution of labour to economic growth. This positive contribution may be attributed to the improved human capital index, especially the health and education component, which improves the productivity of labour. Furthermore, the Nigerian economy is labour intensive; most of the firms' production outlay in Nigeria are driven by manual labour.

\section{CONCLUSION AND RECOMMENDATION}

The study explores the relationship between economic growth, exchange rate and foreign direct investment in Nigeria. This objective is achieved using the ARDL test for cointegration technique for the period ranging from 1981 to 2018. In conclusion, a long-run relationship between economic growth, exchange and foreign direct investment in Nigeria was established. The model also 
found a convergence to the equilibrium at a speed of adjustment of $0.78 \%$ in case of disequilibrium in the economy.

In line with the findings of this study, the following recommendations are made. Nigeria's government should create an enabling atmosphere for private businesses to prosper. Such a conducive business atmosphere that attracts FDI include improved infrastructure base such as good road and stable power supply; political stability; security of lives and properties and favourable tax policy. This enabling business environment to be created will encourage FDI inflow and spurs the production capacity of the local firms. The government should support this sector by giving tax relief, allowing for more production at a cheaper rate. Therefore, it is crucial to pursue policies that will enable foreign companies to invest in their economy by increasing FDI inflow.

Considering that the quality of labour force determines how effective and efficient the contribution of labour would be, it is important to improve Nigeria's labour productivity. It is recommended that the government and private sector agencies concerned should invest more in the country's education and healthcare infrastructure. This is because the country is labour intensive. By this, the Nigerian labour force would be productive locally, but they will be able to compete with their peers globally.

The data for this empirical study is limited between 1981 and 2018; which does not cover up to 2020 as this study was carried out; hence, it is not able to cover the COVID19 era. Thus, future studies can use quarterly data to deal with small observations, especially when a large number of parameters are involved in having a greater degree of freedom.

\section{REFERENCES}

[1] Akinlo, A. E. (2004). Foreign direct investment and growth in Nigeria. An empirical investigation. Journal of Policy Modeling,26(5), 639.https://doi.org/10.1016/j.jpolmod.2004.04.011

[2] Alabi, K. O. (2019). The Impact of Foreign Direct Investment on Economic Growth:Nigeria Experience. Open Journal of Applied Sciences, 09(05), 372385.https://doi.org/10.4236/ojapps.2019.95031

[3] Antwi, S., Ebenezer, M., Mills, G. A., \&Xicang, Z. (2013). Impact of Foreign Direct Investment on Economic Growth:Empirical Evidence from Bangladesh. International Journal of Academic Research in Accounting, Finance andManagement $\quad$ Sciences, 3(1),18-25. https://doi.org/10.5539/ijef.v7n2p178

[4] Asteriou, D., Masatci, K., \&Pilbeam, K. (2016). Exchange rate volatility and international trade: International evidence fromthe MINT countries. Economic
Modelling,58(November 2013), 133-140. https://doi.org/10.1016/j.econmod.2016.05.006

[5] Basirat, M., Nasirpour, A., \&Jorjorzadeh, A. (2014). The effect of exchange rate fluctuations on economic growth considering the level of development of financial markets in selected countries. Asian Economic and Financial Review, 4(4), 517-528. http://www.aessweb.com/pdf-files/aefr 4(4)517-528.pdf

[6] CBN (2018). Central bank of Nigeria statistical bulletin.

[7] Ehimare, A. (2011). The Effect of Exchange Rate and Inflation on Foreign Direct Investment and Its Relationship with Economic Growth in Nigeria. Annals of Dunărea de Jos University. Fascicle I: Economics and Applied Informatics, 1(1), 5-16.

[8] Ehinomen , C. and Oladipo, T.I. (2012).Exchange Rate Management and the Manufacturing Sector Performance in the NigerianEconomy. IOSR Journal of Humanities and Social Science (JHSS) ISSN: 2279-0837, ISBN: 2279-0845. Volume5,Issue 5 (Nov.-Dec. 2012),PP 01-12.

[9] Harris, R., \&Sollis, R. (2003). Applied Time Series Modelling and Forecasting. Wiley: Chichester. ISBN 9780470844434

[10] Kenny, V. S. (2019). Effect of Foreign Direct Investment and Exchange Rate on Economic Growth of Nigeria. SSRN Electronic Journal. https://doi.org/10.2139/ssrn.3357520

[11] Khalighi, L., \&Fadaei, M. S. (2017). A study on the effects of exchange rate and foreign policies on Iranians dates export. Journal of the Saudi Society of Agricultural Sciences, 16(2), 112118.https://doi.org/10.1016/j.jssas.2015.03.005

[12] Mlambo, C. and McMillan, D. (2020)Exchange rate and manufacturing sector performance in SACU states. Journal Cogent Business \& Management Volume 7, 2020 - Issue doi/full/10.1080/23311975.2020.1787735

[13] Mokuolu, J. O. (2018). Effect of Exchange Rate and Interest Rate on FDI And Its Relationship With Economic Growth In Nigeria. 33-47. https://doi.org/10.5281/zenodo.1168515

[14] Nwanji, T.I., Howell, K.E., Faye, S., Otekunrin, A.O., Eluyela, D.F., Lawal, A.I. and Eze, S.C. (2020). Impact of foreign direct investment on the financial performance of listed deposit banks in Nigeria. International Journal of Financial Research, 11(2), 323-347. https://doi.org/10.5430/ijfr.v11n2p323

[15] Ogu, C. (2020). Foreign direct investment and exchange rate in Nigeria. January 2019.

[16] Ojo, A. T., \&Alege, P. O. (2014). Exchange Rate Fluctuations and Macroeconomic Performance in SubSaharan Africa: A Dynamic Panel Cointegration Analysis. Asian Economic and Financial Review, 4(11), 15731591.

[17] Osabohien, R., Osabuohien, E., \&Ohalete, P. (2019). Agricultural sector performance, institutional framework and foodsecurity in Nigeria. Bio-Based and Applied Economics, 8(2), 161-178. https://doi.org/10.13128/bae8929 
[18] Pegkas, P. (2015). The impact of FDI on economic growth in Eurozone countries. The Journal of Economic Asymmetries, 12(2),124-132. Pesaran, M. H., Shin, Y., \& Smith, R. J. (2001). Bounds testing approaches to the analysis of level relationships. Journal of Applied Econometrics, 16(3), 289-326. https://doi.org/10.1002/jae.616

[19] Popoola, O., Asaleye, A. J., \&Eluyela, D. F. (2018). Domestic Revenue Mobilisation and Agricultural Productivity: Evidencefrom Nigeria. Journal of Advanced Research in Law and Economics, 9(4), 1439. https://doi.org/10.14505//jarle.v9.4(34).31

[20] Sokang, K. (2018). The Impact of Foreign Direct Investment on the Economic Growth in Cambodia: Empirical Evidence. International Journal of Innovation and Economic Development, 4(5), 31-38. https://doi.org/10.18775/ijied.184975517020.2015.45.2003

[21] Sunde, T. (2017). Foreign direct investment, exports and economic growth: ADRL and causality analysis for South Africa. Research in International Business and Finance, 41(May), 434- 444. https://doi.org/10.1016/j.ribaf.2017.04.035

[22] Umeora, C. E. (2013). Effects of foreign direct investment (FDI) on economic growth in Nigeria. Anambra State University. Working Paper Series, 14, 1-14.

[23] Uzoma-Nwosu, D., \&Orekoya, S. (2019). Exchange Rate Volatility And Foreign Direct Investment In Nigeria. In Euro Economica (Vol. 38, Issue 2).

[24] World Bank. World Development Indicators. (2020). Retrieved from http://api.worldbank.org/v2/en/country/NGAdownloadforma $\mathrm{t}=\mathrm{csv}$ 